- COMMENTARY

Volume 9 Issue 22017

DOI: 10.21315/eimj2017.9.2.10

ARTICLE INFO

Submitted: 30-04-2017

Accepted: 09-05-2017

Online: 30-06-2017

\section{Clarifying the Instructional Role of Faculty in Medical and Health Professions Programs}

\author{
Kenneth Royal
}

North Carolina State University, Raleigh, NC, USA

To cite this article: Royal K. Clarifying the instructional role of faculty in medical and health professions programs. Education in Medicine Journal. 2017;9(2):75-77. https://doi.org/10.21315/ eimj2017.9.2.10

To link to this article: https://doi.org/10.21315/eimj2017.9.2.10

\begin{abstract}
Many medical educators appear to struggle with their educational identity. Most all faculty will agree that their job is to provide the best instruction (training) possible to students. However, a large contingent of faculty will also agree that they have a responsibility to both their institution and their profession to essentially serve as "gatekeepers of the curriculum" by attempting to distinguish the most able from the least able students. In fact, many calls from graduate medical education encourage such behaviours. Unfortunately, this dual-purpose identity increases the risk of causing significant harm to both instructional effectiveness and student learning. This article discusses the philosophical differences in assessment approaches and challenges educators to consider the question "Is it my job to sort talent, or develop talent?" and respond appropriately with one's teaching and assessment practices.
\end{abstract}

Keywords: Faculty, Medical education, Assessment, Teaching, Instruction, Professional development grading

\section{INTRODUCTION}

Many medical educators appear to struggle with their educational identity. Most all faculty will agree that their job is to provide the best instruction (training) possible to students. However, a large contingent of faculty will also agree that they have a responsibility to both their institution and their profession to essentially serve as "gatekeepers of the curriculum" by attempting to distinguish the most able from the least able students. In fact, many calls from graduate medical education encourage such behaviours (1). Unfortunately, this dual-purpose identity increases the risk of causing significant harm to both instructional effectiveness and student learning.

\section{SORTING VERSUS DEVELOPING TALENT}

Internationally renowned educator Thomas Guskey often asks K-12 teachers a critical question that helps teachers identify their proper role as instructors and assessors. This author would like to pose this same question to instructors in medical and health professions programs. That is, "Is it my job to sort talent or develop talent?" The answer cannot be both, as there is no in-between. If one's purpose is to sort talent, then the instructor must do everything s/he can to maximise differences in students' abilities on all measures of learning. To accomplish this goal, faculty will often:

1. Construct examinations that are unduly rigorous; 
2. Convey instruction that focuses on trivial details and subsequently assess students on minutiae concepts and content;

3. Utilise norm-referenced assessment practices that judge students' performance relative to their peers; and/ or

4. Employ prescribed grade distributions in which a pre-determined percentage of students will receive each possible grade (e.g., the top $15 \%$ of performers will receive an "a"/"honors", etc.).

Each of these practices have been criticised in the research literature due to concerns about appropriateness, effectiveness, fairness and/or validity (2-5).

In truth, most educators in professional medical programs will rarely, if ever, be expected to sort talent. Admissions committees are charged with making selection decisions by sorting talent and selecting the most desirable students to offer admission. Thus, these efforts negate the need for any further talent sorting. However, it is easy to understand how many educators might be confused about their instructional roles. Perhaps the greatest source of confusion is admissions tests (e.g., MCAT, GRE, etc.) whose purpose conflicts with most every other type of tests administered to students (e.g., classroom assessments, licensure examinations, etc.). Admissions tests intend to sort talent by differentiating examinees' abilities using a norm-referenced approach. These types of tests are considered "instructionally insensitive", (6) as examinees are not provided deliberate instruction and subsequently assessed on the material. As with most any instructionally insensitive test, items that fail to discriminate students' abilities (e.g., easy items) are of little value so only a few of these items typically appear on these assessments. Instead, most items are purposefully difficult and possess good discriminatory abilities.

If one's goal is to develop talent, and it ought to be for every educator, then one should go about things differently. First, assessments should be criterion-referenced so that performance relative to a particular standard is measured, as opposed to performance relative to one's peers. Unlike admissions tests, classroom assessments should be "instructionally sensitive", meaning students should be provided instruction and subsequently assessed on that material (7-8). Next, faculty should specify the learning outcomes for their course and identify what specifically students should be able to do by the end of the course. After these expectations are made clear and students are informed of how their performance will be measured, faculty should proceed to do everything possible to maximise learning opportunities for all students and ensure that all students achieve the intended outcomes. If instructors are successful teaching and students are successful learning, there will be little to no variation in students' performance measures. Further, given the immensely talented population of students in any graduate or professional program it is entirely plausible that most every student will receive excellent marks. Thus, one should be careful not to dismiss courses in which most students receive excellent marks as "too easy" or of inadequate quality. In truth, even the most challenging courses ought to yield a gradebook full of high marks when both students and faculty perform their functions excellently.

\section{CONCLUSION}

Many instructors appear to struggle with their educational identity. While virtually all educators are concerned with developing talent, many erroneously believe they should also be concerned with sorting talent. The implications of this mistaken identity can be quite costly with respect to faculty effectiveness and student learning. This author challenges educators to consider the question "Is it my job to sort talent, or develop talent?" and respond appropriately with his or her teaching and assessment practices. 


\section{REFERENCES}

1. Benzinger R. From the desk of the program director: show me the rankings! J Grad Med Educ. 2014;6(3):413-4. https://doi. org/10.4300/JGME-D-13-00448.1.

2. Graffam B. Active learning in medical education: strategies for beginning implementation. Med Teach. 2007;29(1):38. https://doi. org/10.1080/01421590601176398.

3. Rajan TV. Making medical education relevant. Chron High Educ. 2006;52(19):B20.

4. Royal KD, Guskey TR. On the appropriateness of norm- and criterionreferenced assessments in medical education. Ear Nose Throat J. 2015;94(7):252, 254.
5. Royal KD, Guskey TR. The perils of prescribed grade distributions: what every medical educator should know. J Contemp Med Educ. 2014;2(4):240-1. https://doi. org/10.5455/jcme.20150128055155.

6. Popham JW. Instructional insensitivity of tests: accountability's dire drawback. Phi Delta Kappan. 2007;89(2):146-50. https:// doi.org/10.1177/003172170708900211.

7. Haladyna T, Roid G. The role of instructional sensitivity in the empirical review of criterion-referenced test items. J Educ Meas 1981;18:39-53. https://doi. org/10.1111/j.1745-3984.1981.tb00841.x.

8. Royal KD, Hedgpeth MW, Smith KW, Kirk D. A method for investigating "instructional familiarity" and discerning authentic learning. Ann Med Health Sci Res, 2015;5(6):428-34. https://doi. org/10.4103/2141-9248.177990. 